DOI: $10.17516 / 1997-1370-0543$

УДК 343.851

\title{
Corruption Prevention in Educational Organization (Case Study: Siberian Federal University)
}

\author{
Irina A. Damm* \\ Siberian Federal University \\ Krasnoyarsk, Russian Federation
}

Received 08.08.2019, received in revised form 27.12.2019, accepted 10.01.2020

\begin{abstract}
In accordance with the legislation of the Russian Federation on countering corruption, educational organisations are obliged to take measures to prevent corruption. At the same time, the content, forms, methods and subjects of organising anticorruption preventive work are questions that do not have a definite answer. Siberian Federal University implements a set of measures to prevent corruption based on its own scientific findings. Long-term preventive activity predetermined the institutionalisation of relations in corruption prevention at the University. Specialised structural units for corruption prevention, established under local regulatory acts in connection with the increasing complexity of the tasks and emerging needs, successfully operate. The corruption prevention programme annually adopted in Siberian Federal University lays out the specific features of the main directions of work. At the same time, one of the important areas implemented by the organisation is the anti-corruption enlightenment of students and employees, as well as ensuring the information transparency of corruption prevention. In the absence of a proper scientific and methodological basis for corruption prevention in educational institutions of higher education, the experience of Siberian Federal University may be useful for other educational organisations of various types.
\end{abstract}

Keywords: corruption, education, prevention, anti-corruption preventive measures, anticorruption enlightenment, anti-corruption competences, educational organisation.

Research area: law.

Citation: Damm, I.A. (2020). Corruption prevention in educational organization (case study: Siberian Federal University). J. Sib. Fed. Univ. Humanit. Soc. Sci., 13(1), 50-60. DOI: 10.17516/1997-1370-0543

\footnotetext{
(C) Siberian Federal University. All rights reserved

* Corresponding author E-mail address: idamm@sfu-kras.ru ORCID: 0000-0001-6286-374X
} 


\section{Introduction}

Prevention of corruption is one of the important directions of the state policy of modern Russia. At the same time, the main preventive efforts are aimed at the sphere of state and municipal governance. And, if corruption prevention in the system of state and municipal service starts to acquire a systemic nature and bring positive results, corruption prevention in the Russian education is carried out less systematically and intensively.

Corruption in education is increasingly referred to as a threat to the national security of the Russian Federation. This type of corruption is dangerous because various sectors of the national economy of our state, as well as the sphere of public administration, are annually replenished by qualified specialists who may not have real professional competencies due to the use of corrupted assessment methods.

In the educational system deformed by corruption, the process of education and training is reduced to a bargain, the only essence of which is receiving remuneration by a representative of an educational organisation for the use of his/her official position. In such conditions, education becomes a buying and selling relationship, where the level of knowledge acquired, value orientations and practical experience remains outside the bounds of a corrupt bargain.

The high degree of public danger of corruption in the sphere of education predetermined Russian and foreign researchers' increase in scientific interest and study of various aspects of corruption in the field of education. It should be noted that the majority of research works are devoted to corruption prevention in the educational system as a whole (Abramov \& Sokolov, 2017a; Akunchenko, 2017; Volkova, 2018; Bikeev \& Kabanov, 2010, 2019; Du Plessis, 2014; Kabanov, 2014, 2015, 2017; Kosarenko, 2018; Martin, 2016; Mashinian \& Kochergina, 2015; Pliugina, 2016; Poisson, 2013; Polukarov, 2017, 2018 et al.), as well as in educational organisations in particular (Damm \& Shishko, 2016, 2018; Komalasari \& Saripudin, 2015; Koval, 2014; Mikheev, 2014; Vorontsov, 2015 et al.). In turn, when reviewing counteraction issues, the authors more often study matters of preventing corruption in higher education (Andrei et al., 2009; Borisova, 2014; Chapman \& Lindner, 2016; Chekmenev, 2014; Garmaev, 2016; Kirillovykh, 2015; Konnov, 2018; Lyubkina \& Lubsky, 2018; Mitin, 2018; Monakhov \& Zakharov, 2015; Shchedrin, 2009, 2010 et al.).

A comparatively smaller amount of research is devoted to understanding the essence of corruption in the field of education, identifying its characteristics, forms, types and kinds, as well as determinants (Abramov \& Sokolov, 2017b; Denham, 2012; Mozhina, 2019; Popov, 2018; Zinnatullin, 2013 et al.). A part of this gap is filled by a comprehensive dissertation researches of specialists in the fields of jurisprudence, economics and sociology (Bodrov, 2013; Borisova, 2013; Leonteva, 2010; Plokhov, 2011; Povnyi, 2011; Pugach, 2010; Sergeeva, 2018; Slesareva, 2004; Strebkov, 2012 et al.).

At the same time, despite the considerable amount of work, the issue of shaping a systematic approach to corruption prevention in educational organisations remains open.

\section{Theoretical framework}

Corruption in the field of education can manifest itself in educational management relations, as well as in relations on the organisation and maintenance of the educational process.

Education system management is carried out by the relevant state and municipal bodies, which within their competence form a system of interacting bodies exercising management in the field of education (state and municipal), adoption and implementation of programmes aimed at the education system development, conduct monitoring in the education system, informational and methodological provision of the activities of state and municipal bodies engaged in educational management, state regulation of educational activities, etc. (Paragraph 2, Article 89 of the Federal Law "On Education in the Russian Federation").

Organisation of educational activities combines key areas of educational institutions work, namely: the educational process, administrative activities, as well as economic activities to ensure educational process. At the same time, the most pronounced features of corrup- 
tion in education are manifested in the relations developing in the educational process between the professor and the student (his/her representative). In turn, the corruption relations developing in the economic activities of an educational organisation have less pronounced features and are typical for the majority of business entities (Damm, 2016b).

The object of anti-corruption prevention in the field of education has a complex nature and combines social relations, phenomena and processes in the field of education, which determine the emergence and existence of corruption. The object of anti-corruption prevention can be both material (practical) aspects of human activity, society and the state, and spiritual ones.

The subjects of anti-corruption prevention in the field of education include all subjects of combating corruption in the above-mentioned sphere, which implement a set of non-coercive measures regarding the object of anti-corruption prevention. Classifications and typologies of subjects of anti-corruption prevention in the field of education are possible on various grounds and groups of symptoms. The complex of anti-corruption prevention measures in the field of education is of key importance in the considered preventive system.

Implementation of anti-corruption prevention measures in the sphere of education is possible using various non-coercive methods, techniques and means. Means (methods) of anti-corruption prevention differ in the form of carrying out (conducting) an event, the source of information transfer and the degree of involvement of those being prevented in the event, the degree of management, etc. Techniques of anti-corruption prevention are separate, specific operations or actions of the subject of prevention, allowing the solution of certain preventive tasks (Damm, 2019).

Corruption prevention is an independent direction of combating corruption and, as applied to educational organisations, it is necessary to define conceptual and theoretical approaches as well as strategic planning of the activity under consideration at the level of state anti-corruption policy.

\section{Statement of the problem}

The adoption in 2008 of the Federal Law "On Combating Corruption" and the subsequent active by-law rule-making and creation of organisational foundations for countering corruption was a powerful impetus for the educational management development, as well as for the entire state governance of Russia. For educational institutions, as well as other organisations, the starting point was the introduction in 2012 of the Federal Law "On Combating Corruption" Article 13.3 "The Obligation of Organisations to Take Measures to Prevent Corruption".

The later inclusion of this article in the Federal Law "On Combating Corruption" predetermined the general lag in the system for preventing corruption and anti-corruption prevention in educational institutions as compared to similar activities in state and municipal bodies that manage the education system.

The first part of the above-mentioned norm provides for the obligation of organisations to develop and take measures to prevent corruption. Part two stipulates that measures to prevent corruption taken in an organisation may include, for example, identifying units or officials responsible for corruption and other offenses prevention (Paragraph 1, Part 2); cooperation of the organisation with law enforcement agencies (Paragraph 2, Part 2); development and implementation of standards and procedures aimed at ensuring good work of an organisation; adoption of the code of ethics and official conduct of employees of an organisation (Paragraph 4, Part 2); preventing and resolving conflicts of interest (Paragraph 5, Part 2).

Accordingly, Article 13.3, "The Obligation of Organisations to Take Measures to Prevent Corruption", establishes the duty for organisations to take measures to prevent corruption and contains an approximate list of measures that may be accomplished by an organisation at its discretion. Thus, educational organisations are obliged to prevent corruption. However, the conceptual, scientific-methodological, organisational, and coordinating bases for the corruption prevention in educational organisations are at an early stage of their development. Under current conditions, educational institu- 
tions are obliged to form and implement their anti-corruption policy to the best of their abilities, resources and initiatives.

\section{Discussion}

Siberian Federal University's anti-corruption policy is an important component of the University's activities which is subject to the University leadership's great attention. Despite the shortcomings in the research and methodological provision for corruption prevention at the level of organisations, Siberian Federal University (hereinafter - SibFU) independently develops and implements a set of anti-corruption measures to prevent corruption in the institution.

Thus, in 2016 the University established the Center for Corruption Counteraction and Legal Expertise of Siberian Federal University. This structural unit is called to provide research and methodological support of the educational institution anti-corruption policy. In addition to the Center, the Anti-Corruption Student Club of Siberian Federal University, a self-regulating anti-corruption student organisation whose members have been conducting research on corruption since 2007, as well as participating in the implementation of anti-corruption activities of the University and the region, operates in SibFU. The Club members are volunteers of the Center. It should be noted that all staff of the Center are former members of the Club.

The activities of the Center, the Club and other structural units authorised for the implementation of certain activities are carried out in accordance with the SibFU Anti-Corruption Programme which is annually adopted.

The programme provides for the implementation of anti-corruption preventive activities in the following areas:

- monitoring of corruption and the level of perception of corruption by the students and employees of Siberian Federal University;

- conducting anti-corruption expertise and introducing changes to local regulatory legal acts of SibFU;

- development and implementation of the legal and organisational framework for preventing corruption in SibFU;
- anti-corruption education of the students and employees of SibFU;

- anti-corruption enlightenment of the students and employees of SibFU;

- identification and prevention of corruption-related situations in SibFU;

- establishment of a feedback system and a rapid response to complaints and appeals about corruption in SibFU;

- interaction of SibFU with governmental bodies, local governments, organisations and civil society institutions on the issues of preventing and combating corruption.

At the same time, the activities of the programme within the areas under consideration vary annually depending on the actual needs of the university in shaping students and employees' specific anti-corruption competencies or implementing organisational and supporting activities (developing and updating information in the "Anti-Corruption" section, placing stands with anti-corruption information, etc.).

Within the programme, sociological studies were conducted to monitor corruption and the level of perception of corruption by the students and employees of Siberian Federal University (Damm et al., 2018), a special expert workshop on anti-corruption expertise was held to exclude corruption-related factors in the local regulatory legal acts adopted by the organisation (Seminar, 2018), educational programmes on combating corruption were developed to implement anti-corruption education of students and staff (Training programs, 2019), etc.

Special attention in the educational institution is paid to the anti-corruption education of students and employees, since it is anti-corruption education that is one of the main means of forming an intolerant attitude towards corrupt behaviour in society.

The programme on anti-corruption education for 2014-2016, approved by Decree No. 816-p of the Government of the Russian Federation of May 14, 2014 pays great attention to the educational environment. In accordance with subparagraph " $\%$ " of Paragraph 21 of the National Anti-Corruption Plan for 2018-2020, the Government of the Russian Federation, with the 
participation of the Prosecutor General's Office of the Russian Federation, is tasked with preparing proposals for the development of a set of educational measures aimed at creating an atmosphere of intolerance towards corruption in society, including increasing the effectiveness of anti-corruption education. However, there is no generally accepted approach to the content and forms of anti-corruption educational activities, as well as to the ways of forming an intolerant attitude towards corruption.

Accessible dissemination of knowledge about socio-legal nature, forms of existence and negative consequences of committing corruption offences, as well as overcoming the corrupt stereotypes prevalent in the Russian society is a priority for preventive work in an educational organisation.

Anti-corruption enlightenment in SibFU is carried out using various forms and means.

Thus, "Anti-Corruption" rubric (Anti-Corruption, 2019) placed on the official website of the University contains all the necessary anti-corruption materials for employees and students, including section on conflicts of interest.

On the basis of the Anti-Corruption Student Club of Siberian Federal University, the University regularly hosts anti-corruption events in the form of simulation games and discussion platforms with representatives of law enforcement agencies.

For example, on May 5, 2016, a round table meeting of the Club was held with the participation of the head of the Krasnoyarsk Investigation Department for Transport of the West-Siberian Investigation Department for Transport of the Investigative Committee of the Russian Federation; on March 23, 2016, in association with the Election Commission of Krasnoyarsk Krai, the "Brain Ring" game dedicated to the issues of identification and prevention of corruption in the electoral process was organised; on December 9, 2015, the Election Commission of Krasnoyarsk Krai and SibFU Intellectual Games Club in association with the Office of the Governor of Krasnoyarsk Krai on security, corruption and other offences prevention conducted an intellectual anti-corruption game "Who? Where? How much?" among the teams of eight institutes of Siberian Federal University.

Despite the fact that anti-corruption enlightenment-raising activities have been held in Siberian Federal University since 2007, it has become obvious that the level of anti-corruption literacy of the students and the staff does not change significantly. Sporadic anti-corruption actions do not bring the desired result. After analysing judicial practice, as well as the results of anti-corruption education activities carried out in Krasnoyarsk Krai, the expert research and practical community in the field of anti-corruption came to the conclusion that it was necessary to jointly develop the content, forms and methods of anti-corruption enlightenment in the field of education.

The SibFU Center for Corruption Counteraction and Legal Expertise, SibFU Law School in association with the Krasnoyarsk regional branch of the "Russian Society "Znanie", with the support of the Ministry of Education of Krasnoyarsk Krai, as well as with the grant support of the Youth Policy Agency and the implementation of social development programmes of Krasnoyarsk Krai devised the Anti-Corruption Educational Complex "Fundamentals of Anti-corruption Enlightenment in the Field of Education".

The idea of the project is that experts in the field of combating corruption, criminal law, criminology, psychology and other sciences will jointly devise the Anti-Corruption Methodological Enlightenment Complex. Further, the developers of the complex will train representatives of educational organisations who, having "armed themselves" with the materials of the complex, will independently conduct anti-corruption enlightenment sessions for their colleagues.

Anti-Corruption Methodological Enlightenment Complex (Akunchenko et al., 2017) includes:

a) Presentation to conduct an enlightenment event in an educational institution.

The presentation consistently addresses three main enlightenment modules: "Corruption", "Corruption Prevention" and "Major Corruption-Related Stereotypes". Each module elucidates basic material in a simple and accessible 
form supported by necessary images and diagrams. The most complicated issues, such as differentiation between a gift and a bribe, a minimum amount of a bribe, legitimacy of tutoring services, as well as others are explained in the course of a video consultation by the representatives of Krasnoyarsk Krai Prosecutor's Office, the Main Investigation Department of Krasnoyarsk Krai Investigative Committee, the Federal Tax Service of Russia for Krasnoyarsk Krai, Doctors of Law of Siberian Federal University Law School, International Institute for Educational Planning of UNES$\mathrm{CO}$.

b) Manual for self-study (Akunchenko et al., 2016). The manual is designed to help a lecturer prepare for the anti-corruption enlightenment class without resorting to additional literature. The manual, according to the presentation, addresses the main enlightenment modules together with the necessary theoretical explanations, normative reasoning and referring to judicial practice.

c) Normative legal acts on the aforesaid subject area. The complex is accompanied by the full texts of the regulatory documents necessary for the enlightenment event proper preparation.

d) Visual aids for anti-corruption agitation and propaganda. To provide the opportunity to diversify their enlightenment session, lecturers are offered a number of videos with the winners of anti-corruption social advertising and propaganda competitions.

The presentation of the complex accounts for one anti-corruption enlightenment session lasting 1.5-2 academic hours.

The elaborated Anti-Corruption Methodological Enlightenment Complex was first presented on September 15, 2016 at the II Siberian Anti-Corruption Forum "Urgent Issues of Anti-Corruption Enlightenment and Education" and aroused great interest among the pedagogical community of the region. Critical remarks and a number of proposals were made during the Forum.

In particular, it should be noted that the holding of an annual anti-corruption forum is also an initiative of the University, allowing to involve various subjects of the anti-corrup- tion system in discussing current problems and jointly finding ways to solve them.

After the completion of the Complex, the developers conducted two training seminars for scientific and pedagogical (including a representative from each of 20 institutes of Siberian Federal University) and other employees of Siberian Federal University (including a representative from administrative, economic and other departments). Each trained employee received a disk containing the complex and, after self-training, carried out anti-corruption enlightenment for the employees of the structural unit he/she works for. In total, 80 employees were trained during the training seminars, and already trained employees educated the vast majority of employees in all structural divisions of the University. Thus, in 2016 in Krasnoyarsk Krai, a unique project on mass anti-corruption enlightenment in the field of education was fulfilled on the basis of Siberian Federal University (Damm, 2016a).

Without stopping at what has been achieved, in 2018 and 2019 the Center and the Club, together with the department of the Governor of Krasnoyarsk Krai on security, corruption and other offences prevention, implemented the unique project "A Week of Anti-Corruption Initiatives in SibFU". Thus, in 2018 within the framework of the project, a competition for the best anti-corruption initiative was organised as well as the Anti-Corruption Dictation was devised and conducted (Anti-Corruption, 2019). The purpose of the dictation was to identify defects and gaps in the students and the employees' knowledge about corruption, its forms and responsibility for commission of corruption related offences. Immediately after the Dictation, the staff of the Center and the Club's activists discussed the issues of the participants' interest.

In addition, in 2019 the Anti-Corruption Intellectual Game "What? Where? When?" was held among SibFU institutes. An important event in the students' life was holding of the constituent assembly and the first meeting of the Youth Council for the Prevention of Corruption under the SibFU Rector (hereinafter referred to as the Council). The main Council's tasks are to devise and submit pro- 
posals to the Rector to improve the University anti-corruption policy, to assist the University leadership in corruption preventive measures implementation. The initiative to create a new youth association at the University belongs to the Center and the Club and is dictated by the need to involve young people in active personal anti-corruption activities. The coordination of the activities of the Council is carried out by the Center.

\section{Conclusion}

Thus, SibFU has formed the legal and organisational framework for corruption prevention. Long-term consistent work aimed at ensuring the proper content of anti-corruption preventive activities predetermined the institutionalisation of relevant relations. The University has established special structural divisions and student associations that operate on the basis of the approved legal provisions: the Center for Corruption Counteraction and Legal Expertise of Siberian Federal University, the Youth Council for the Prevention of Corruption under the Rector of Siberian Federal University, and the Anti-Corruption Student Club of Siberian Federal University.
The key areas of corruption prevention in an educational institution are annually set forth in the University's programme for the current academic year, which is implemented by the above-mentioned special divisions and students' organisations with the full support of the University leadership. The content of the corruption prevention programme is elaborated by the Center on the basis of its own research findings, current scientific achievements of Russian and foreign scientists, as well as the practical experience of other educational institutions.

Taking into account the fact that information transparency is important in ensuring the fight against corruption, the results of the University's anti-corruption activities are regularly covered on the official website under the special heading "Anti-Corruption" and "The New University Life" newspaper.

We believe that corruption prevention should be an integral part of every educational organisation mission. At the same time, the complex nature of the measures taken is important. Siberian Federal University carries out its anti-corruption policy in this direction. We hope our experience will be of use to other educational institutions.

\section{References}

Abramov, R.A., Sokolov, M.S. (2017a). Evaluation of the Effectiveness of Russian Anti-Corruption State Policy in the Field of Education. In Journal of Legal, Ethical and Regulatory Issues, 20 (1).

Abramov, R.A., Sokolov, M.S. (2017b). Features of Corruption in the Educational Sphere in the Context of Globalization of Educational Space. In Journal of Legal, Ethical and Regulatory Issues, 20 (1).

Akunchenko, E.A. (2017). K voprosu ob organizatsionno-pravovykh osnovakh antikorruptsionnogo prosveshcheniia v sfere obrazovaniia [Issues of the Organizational and Legal Basis of Anti-Corruption Education]. In Nauka i shkola [Science and School], 1, 20-28.

Akunchenko, E.A., Vyrva, P.A., Damm, I.A. (ed.), Koval, Iu.A., Konstantinov, A.S., Sukhareva, K.S., Shchedrin, N.V. (ed.), Ianov, O.A. (2016). Osnovy antikorruptsionnogo prosveshcheniia v sfere obrazovaniia: uchebnoe posobie [Fundamentals of Anti-Corruption Enlightenment in the Field of Education: textbook]. Krasnoyarsk, SibFU, 200 p.

Akunchenko, E.A., Vyrva, P.A., Damm, I.A. (ed.), Koval, Iu.A., Konstantinov, A.S., Sukhareva, K.S., Shchedrin, N.V., Ianov, O.A. (2017). Osnovy antikorruptsionnogo prosveshcheniia $v$ sfere obrazovaniia: uchebno-metodicheskii kompleks [Fundamentals of Anti-Corruption Enlightenment in the Field of Education: methodological complex]. Krasnoyarsk, SibFU.

Andrei, T., Teodorescu, D., Bourbonnais, R., Oancea, B. (2009). A Simultaneous Equation Model for Estimating Corruption in Higher Education. In Acta Oeconomica, 59 (4), 411-439.

Anti-Corruption, 2019. Protivodeistvie korruptsii v Sibirskom federalnom universitete [Anti-Corruption Measures in Siberian Federal University]. Available at: http://anticorruption.sfu-kras.ru/ (accessed July 17, 2019). 
Bikeev, I.I., Kabanov, P.A. (2010). Antikorruptsionnoe obrazovanie v Rossii: sostoianie i perspektivy [Anti-Corruption Education in Russia: State and Prospects]. In Biznes. Obrazovanie. Pravo. Vestnik Volgogradskogo instituta biznesa [Business. Education. Law. Bulletin of the Volgograd Business Institute], 3, 178-188.

Bikeev, I.I., Kabanov, P.A. (2019). Antikorruptsionnoe prosveshchenie: voprosy teorii i praktiki [Anti-Corruption Enlightenment: Issues of Theory and Practice]. Kazan, Poznanie, 240 p.

Bodrov, N.F. (2013). Ispol'zovanie spetsial'nykh znanii pri rassledovanii vziatochnichestva i drugikh proiavlenii korruptsii v sfere obrazovaniia [The Use of Special Knowledge in the Investigation of Bribery and Other Manifestations of Corruption in the Field of Education], $\mathrm{PhD}$ diss., Moscow State Law University.

Borisova, E. (2014). An Analysis of the Mechanisms of the Social Control of Corruption in the Higher Education System. In Russian Education and Society, 56 (4), 27-39.

Borisova, E.A. (2013). Korruptsiia v sisteme vysshego obrazovaniia: perspektivy sotsialnogo kontrolia (regional'nyi aspekt) [Corruption in the System of Higher Education: Prospects of Social Control (Regional Aspect)], PhD diss., Modern Academy of Humanities.

Chapman, D.W., Lindner S. (2016). Degrees of Integrity: The Threat of Corruption in Higher Education. In Studies in Higher Education, 41 (2), 247-268.

Chekmenev, D.S. (2014). K voprosu o komissiiakh po uregulirovaniiu sporov kak elementa organizatsionno-pravovogo mekhanizma razresheniia konfliktnykh situatsii mezhdu studentami i drugimi uchastnikami obrazovatelnykh otnoshenii [On the Issue of Commissions for the Settlement of Disputes as an Element of the Institutional and Legal Mechanism for Resolving Conflict Situations Between Students and Other Participants in Educational Relations]. In Vestnik Piatigorskogo gosudarstvennogo lingvisticheskogo universiteta [Bulletin of Pyatigorsk State Linguistic University], 4, 425-430.

Damm, I.A. (2016a). Antikorruptsionnoe prosveshchenie v sfere obrazovaniia v Krasnoiarskom krae [Anti-Corruption Education in the Krasnoyarsk Region]. In Aktualnye voprosy protivodeistviia korruptsii v subieektakh Rossiiskoi Federatsii [Relevant Issues of Combating Corruption in the Subjects of the Russian Federation]. Kazan, 246-251.

Damm, I.A. (2016b). Korruptsiia v sfere obrazovaniia: poniatie, kharakternye cherty, formy i vidy [Corruption in Education: Concept, Characteristics, Forms and Types]. In Aktualnye problemy ekonomiki i prava [Actual Problems of Economics and Law], 4, 5-17.

Damm, I.A. (2019). Antikorruptsionnaia profilaktika v sfere obrazovaniia: voprosy teorii i praktiki [Anti-Corruption Prevention in Education: Questions of Theory and Practice]. In Pravo i politika [Law and Politics], 8, 18-27.

Damm, I.A., Akunchenko, E.A., Volkova, M.A. (2018). Monitoring otnosheniia k korruptsii v obrazovatel'noi organizatsii [Monitoring Attitudes towards Corruption in Educational Organisations]. In Aktual'nye problemy antikorruptsionnogo prosveshcheniia i antikorruptsionnogo obrazovaniia [Topical Issues of Anti-Corruption Enlightenment and Anti-Corruption Education]. Krasnoyarsk, 128-136.

Damm, I.A., Shishko, I.V. (2016). Corruption Prevention in Russian Education. In Journal of Siberian Federal University, Humanities and Social Sciences, 9 (9), 378-392.

Damm, I.A., Shishko, I.V. (2018). Preduprezhdenie korruptsionnykh riskov pri provedenii gosudarstvennoi itogovoi attestatsii v shkole i vuze: pravovoi aspect [Prevention of Corruption Risks During the State Final Certification in Schools and Universities: The Legal Aspect]. In Iuridicheskie issledovaniia [Legal Studies], 12, 11-29.

Denham, S.C. (2012). La corrupción en sistemas educativos: Una revisión de prácticas, causas, efectos y recomendaciones [Corruption in Education Systems: A Review of Practices, Causes, Effects and Recommendations]. In Revista Electronica de Investigacion Educativa, 14 (2), 52-72.

Du Plessis, P. (2014). Corruption in Education - Stealing the Future. In Mediterranean Journal of Social Sciences, 5 (23), 1308-1316.

Garmaev, Iu.P. (2016). Antikorruptsionnoe prosveshchenie v vuzakh [Anti-corruption Education in Universities]. In Problemy pravovogo obespecheniia bezopasnosti lichnosti, obshchestva i gosudarstva [Problems of Legal Security of the Individual, Society and the State]. Novosibirsk, 189-197. 
Kabanov, P.A. (2014). Antikorruptsionnoe prosveshchenie kak sredstvo protivodeistviia korruptsii: poniatie i soderzhanie [Anti-Corruption Enlightenment as a Means of Countering Corruption: The Concept and Content]. In Aktual'nye problemy ekonomiki i prava [Actual Problems of Economics and Law], 4, 42-51.

Kabanov, P.A. (2015). Poniatie i soderzhanie antikorruptsionnogo prosveshcheniia kak sredstva profilaktiki korruptsii [Concept and Content of Anti-Corruption Enlightenment as a Means of Preventing Corruption]. In IUridicheskie issledovaniia [Legal Studies], 2, 12-27.

Kabanov, P.A. (2017). Viktimologicheskoe antikorruptsionnoe prosveshchenie: poniatie, soderzhanie, formy i sredstva osushchestvleniia [Victimological Anti-Corruption Enlightenment: The Concept, Content, Forms and Means of Implementation]. In IUridicheskie issledovaniia [Legal Studies], 6, 38-64.

Kirillovykh, A.A. (2015). Publichnaia sluzhba i konflikt interesov v sfere vysshego obrazovaniia: problemnye voprosy [Public Service and Conflict of Interest in Higher Education: Problematic Issues]. In Zakonodatelstvo i ekonomika [Legislation and Economics], 2, 29-43.

Komalasari, K., Saripudin, D. (2015). Integration of Anti-Corruption Education in School's Activities. In American Journal of Applied Sciences, (12) 6, 445-451.

Konnov, I.A. (2018). Pravovye osobennosti i mery po protivodeistviiu korruptsii v organizatsiiakh vysshego obrazovaniia [Legal Features and Anti-Corruption Measures in Higher Education Institutions]. In Evraziiskii iuridicheskii zhurnal [Eurasian Law Journal], 9, 323-325.

Kosarenko, N.N. (2018). Protivodeistvie korruptsii v sfere obrazovaniia [Anti-Corruption in the Field of Education], In Uchenye trudy Rossiiskoi akademii advokatury i notariata [Scientific Works of the Russian Academy of Advocacy and Notary], 1, 89-93.

Koval, Iu.A. (2014). K voprosu o situatsiiakh konflikta interesov v sfere obrazovaniia [Concerning the Situations of Conflict of Interest in Education Sphere]. In Teoriia i praktika obshchestvennogo razvitiia [Theory and Practice of Social Development], 4, 253-255.

Leonteva, E.O. (2010) Institualizatsiia neformalnykh praktik $v$ sfere vysshego obrazovaniia [Institutionalization of Informal Practices in Higher Education], Dr.Sc. diss., Pacific State University.

Lyubkina, N.A., Lubsky R.A. (2018). Korruptsiia v sfere vysshego obrazovaniia: osnovnye problemy i sposoby ikh razresheniia v sovremennom rossiiskom obshchestve [Corruption in the Field of Higher Education: The Main Problems and Ways to Solve Them in Modern Russian Society]. In Iurist-Pravoved [Lawyer-Legist], 3, 64-69.

Martin, M. (2016). External Quality Assurance in Higher Education: How Can It Address Corruption and Other Malpractices? In Quality in Higher Education, 22 (1), 49-63.

Mashinian, A.A., Kochergina, N.V. (2015). Protivodeistvie korruptsii v obrazovanii: neobkhodimost' antikrizisnogo $\mathrm{i}$ antikorruptsionnogo analiza $\mathrm{v}$ rossiiskoi sisteme obrazovaniia [Counteraction of Corruption in Education: Need of the Anti-Resessionary and Anti-Corruption Analysis in the Russian Education System]. In Perspektivy nauki i obrazovaniia [Perspectives of Science and Education], 4, $37-40$.

Mikheev, V.A. (2014). Novatsii i konflikty v sisteme vysshego obrazovaniia sovremennoi Rossii [Innovations and Conflicts in the System of Higher Education in Modern Russia]. In Konfliktologiia [Conflictology], 3, 176-191.

Mitin, A.N. (2018). O kontrole za riskami korruptsionnogo svoistva v sfere vysshego obrazovaniia [On Controlling the Risks of Corruption in Higher Education]. In Rossiiskoe pravo: obrazovanie, praktika, nauka [Russian Law: Education, Practice, Researches], 1, 13-19.

Monakhov, O.N., Zakharov, N.V. (2015). Konflikt interesov prepodavatelia vuza v sisteme protivodeistviia korruptsii [Conflict of Interests of a University Teacher in the Anti-Corruption System]. In Aktual'nye voprosy sovremennoi nauki [Actual Issues of Modern Science], 39, 253-264.

Mozhina, O.Iu. (2019). Osnovnye faktory, determiniruiushchie poluchenie i dachu melkoi vziatki v sferakh zdravookhraneniia i obrazovaniia [The Main Factors Determining Small Passive and Active Bribery in Health and Education Areas]. In Vestnik Kazanskogo iuridicheskogo instituta MVD Rossii [Bulletin of the Kazan Law Institute of the Ministry of Internal Affairs of Russia], 1, 55-61. 
Pliugina, I.V. (2016). Pravovye mekhanizmy preduprezhdeniia korruptsii v sfere obrazovaniia [Legal Mechanisms to Prevent Corruption in Education]. In Zhurnal rossiiskogo prava [Russian Law Journal], 12, 123-133.

Plokhov, S.V. (2013). Protivodeistvie korruptsionnoi prestupnosti v sotsialnoi sfere: na primere zdravookhraneniia i obrazovaniia volgogradskoi i Saratovskoi oblastei [Anti-Corruption Crime in the Social Sphere: The Example of Public Health and Education in the Volgograd and Saratov regions], PhD diss., Saratov State Law Academy.

Poisson, M. (2013). Grabbing in the Education. In Corruption, grabbing and development: Real world challenges. Cheltenham, Edward Elgar Publishing Ltd, 58-67.

Polukarov, A.V. (2017). Administrativno-pravovye sredstva protivodeistviia korruptsii v sotsialnoi sfere [Administrative and Legal Means of Combating Corruption in the Social Sphere]. Moscow, Unity-Dana, $207 \mathrm{p}$.

Polukarov, A.V. (2018). Administrativno-prinuditel'nye sredstva protivodeistviia korruptsii v sotsialnoi sfere [Administrative Coercive Means of Combating Corruption in the Social Sphere]. In Gosudarstvo i parvo [State and Law], 2, 49-58.

Popov, M.Iu. (2018). Korruptsiia i sovremennoe rossiiskoe obrazovanie [Corruption and Modern Russian Education]. In Gumanitarnye, sotsialno-ekonomicheskie i obshchestvennye nauki [Humanities, Socio-Economic and Social Sciences], 12, 47-50.

Povnyi, D.A. (2011). Administrativnye protsedury kak sredstvo protivodeistviia korruptsii v obrazovanii Rossiiskoi Federatsii [Administrative Procedures as a Means of Countering Corruption in the Education of the Russian Federation], PhD diss., South Ural State University.

Pugach, V.N. (2010). Vzaimodeistvie kachestva obrazovaniia i ekonomicheskoi bezopasnosti Vuza [The Interaction of the Quality of Education and Economic Security of the University], PhD diss., Moscow Academy of Economics and Law.

Seminar, 2018. V SFU sostoialsia ekspertnyi seminar po voprosam antikorruptsionnoi ekspertizy [An Expert Seminar on Anti-Corruption Expertise Was Held at Siberian Federal University]. Available at: http://news.sfu-kras.ru/node/21126/ (accessed July 17, 2019).

Sergeeva, Iu.S. (2018). Formirovanie u studentov - budushchikh bakalavrov iurisprudentsii kompetentnosti v sfere protivodeistviia korruptsii [Formation in Students - Future Bachelor of Jurisprudence Competence in the Field of Combating Corruption], PhD diss., Institute of Education Management.

Shchedrin, N.V. (2009). Korruptsiia v "zakone" [Corruption in Legislation], In Rossiiskii kriminologicheskii vzgliad [Russian Criminological Outlook], 3, 351-352.

Shchedrin, N.V. (2010). O neobkhodimosti antikorruptsionnoi ekspertizy tselevogo priema v vuzy [On the Need for Anti-Corruption Expertise of Targeted Admission to Universities]. In Aktual'nye problemy profilaktiki korruptsii v Rossii na sovremennom etape [Relevant Problems of Preventing Corruption in Russia at the Present Stage]. Krasnoyarsk, 88-92.

Slesareva, E.V. (2004). Institutsional'nye reformy v sfere obrazovaniia v Rossii i za rubezhom (Teoriia i praktika) [Institutional Reforms in Education in Russia and Abroad (Theory and Practice)], $\mathrm{PhD}$ diss., Russian Pedagogical University.

Strebkov, Iu.P. (2012). Korruptsionnye prestupleniia v sfere obrazovaniia [Corruption Crimes in Education], PhD diss., Peoples' Friendship University of Russia.

Training programs, 2019. Programmy povysheniia kvalifikatsii, razrabotannye Tsentrom protivodeistviia korruptsii i pravovykh ekspertiz SFU [Training Programmes Developed by the Center for Anti-Corruption and Legal Expertise of Siberian Federal University]. Available at: http://structure.sfu-kras. ru/node/2327\#section2/ (accessed July 17, 2019).

Volkova, M.A. (2018). Rol' igrovykh tekhnologii v antikorruptsionnom prosveshchenii molodezhi (na primere intellektual'noi igry "Kto? Gde? Skolko?") [The Role of Gaming Technology in Anti-Corruption Enlightenment of Youth (Case Study: Intellectual Game “Who? Where? How much?")], In Aktual'nye problemy antikorruptsionnogo prosveshcheniia i antikorruptsionnogo obrazovaniia [Relevant Problems of Anti-Corruption Enlightenment and Anti-Corruption Education]. Krasnoyarsk, 22-28. 
Vorontsov, S.A. (2015). Ob organizatsii antikorruptsionnogo prosveshcheniia v Rossiiskoi Federatsii [On the Organization of Anti-Corruption Enlightenment in the Russian Federation]. In Severo-Kavkazskii iuridicheskii vestnik [North Caucasus Legal Vestnik], 1, 105-111.

Zinnatullin, N.Z. (2013). Determinanty korruptsii v sfere vysshego professional'nogo obrazovaniia [Determinants of Corruption in Higher Professional Education]. In Iuridicheskaia nauka [Legal Science], $1,55-59$.

\title{
Предупреждение коррупции в образовательной организации (на примере Сибирского федерального университета)
}

\author{
И.А. Дамм \\ Сибирский федеральный университет \\ Российская Федерачия, Красноярск
}

\begin{abstract}
Аннотация. В соответствии с законодательством Российской Федерации о противодействии коррупции образовательные организации обязаны принимать меры по предупреждению коррупции. Вместе с тем, содержание, формы, методы и субъекты организации антикоррупционной профилактической работы - вопросы, не имеющие однозначного ответа. Сибирский федеральный университет реализует комплекс мер по предупреждению коррупции на основе собственных научных разработок. Многолетняя предупредительная деятельность предопределила институционализацию отношений по предупреждению коррупции в университете. По мере усложнения задач и на основе возникающих потребностей локальными нормативными актами созданы и успешно функционируют специализированные структурные подразделения по предупреждению коррупции. Основные направления работы детализируются в ежегодно принимаемой программе по предупреждению коррупции в СФУ. При этом одним из важных направлений, реализуемых организацией, является антикоррупционное просвещение обучающихся и сотрудников, а также обеспечение информационной открытости деятельности по предупреждению коррупции. В отсутствие надлежащей научно-методологической основы предупреждения коррупции в образовательных организациях высшего образования опыт Сибирского федерального университета может быть полезен и другим образовательным организациям различного типа.
\end{abstract}

Ключевые слова: коррупция, образование, предупреждение, антикоррупционная профилактика, антикоррупционное просвещение, антикоррупционные компетенции, образовательная организация.

Научная специальность: 12.00.00 - юридические науки. 